\title{
EFFECT OF EGYPTIAN CLOVER HAY SUBSTITUTION WITH SUGAR BEET PULP ON GROWING RABBITS PERFORMANCE
}

\author{
Salah El-Din S. Aboul-Ela and F.M. Reda* \\ Poult. Dept., Fac. Agric., Zagazig Univ., Egypt
}

\begin{abstract}
This work was carried out to study the effect of Egyptian clover hay substitution with sugar beet pulp on growing rabbits performance, carcass traits, digestability of nutrients, feeding values and economical efficiency. Eighty unsexed New-Zealand White (NZW) growing rabbits of 5 weeks were randomly allotted into 5 equal groups (16 rabbits each, with 8 replicates each of two rabbits) to study the effect of substituting Egyptian clover hay $(\mathrm{CH})$ by sugar beet pulp (SBP) at different rates on growing rabbits performance. Five diets were fed to NZW rabbits from 5-13 weeks of age. The first group was fed the basal diet as a control, while the other four groups were fed diets contaning 9, 18, 27 and 36\% SBP, respectivaly which represents replacment rate of 25, 50, 75 and $100 \%$ of $\mathrm{CH}$ in the control diet. Growth performance, carcass traits, digestability coeffecient and feeding values were studied. Results showed that, replacing $\mathrm{CH}$ in the control diet with SBP up to $75 \%$, significantly increased $(\mathrm{P}<0.01)$ live body weight (LBW) and body weight gain (BWG) of the most ages during the experimental period. Rabbits fed 25, 50 and 75\% SBP instead of $\mathrm{CH}$ recorded the highest viability values. Daily feed intake (FI) was insignificantly decreased with increasing the most levels of $\mathrm{CH}$ substitution with SBP while feed conversion $(F C)$ values were significantly $(P<0.05)$ improved with increasing levels of SBP during the most ages of the experimental period. The inclusion of SBP replacement of $\mathrm{CH}$ up to $75 \%$ had a significantly $(\mathrm{P}<0.05$ ) positive effect on the digestibility coefficients of CP and NFE. Each of DCP, TDN and DE were gradually increased $(P<0.01)$ when 25 , 50 and 75\% SBP replaced CH in control diet. All carcass characteristics studied, length of each part of the gastrointestinal tract and $\mathrm{pH}$ of digestive tract were not significantly affected by feeding the SBP diets. The best efficiency value was for the rabbits fed $75 \%$ SBP substitution of $\mathrm{CH}$, followed by 100 , 50 and 25\% SBP replacements. Results obtained seemed to justly the following conclusion: From the nutritional and economical point of view, using SBP up to 75\% substitution for $\mathrm{CH}$ (27\%) in growing NZW rabbit diets had no adverse effect on each of growth performance, viability rate, digestion coefficients, carcass characteristics and digestive tract measurements.
\end{abstract}

Key words: Rabbits, growth performance, carcass charactersitic, digestiblity coefficient, substitution, Egyptian clover hay, sugar beet pulp.

\section{INTRODUCTION}

In developing countries, there is a shortage of both energy sources and feedstuffs with acceptable protein content for animal production. In view of the world wide demand for additional feed sources, the exploitation of traditional crops, which often are grown with low inputs, and are largely adapted to the climatic conditions of the developing countries, would be a step towards better resource utilization (Kebede, et al., 2008; MirzaeiAghsaghali and Maheri-Sis., 2008).

The soluble fibre (SF) may be considered as a functional nutrient in rabbit diets as it promotes changes in intestinal microbiota and gut barrier and it decreases mortality (Carabaño et al., 2008; Xiccato et al., 2011). However, the mechanism by which SF regulates these effects is not clear. In rabbit diets, sugar beet pulp (rich

*Corresponding author: Tel. : +201117166731

E-mail address: fayizreda@yahoo.com 
in pectins) is the preferred raw material to increase dietary SF level. However, the physical and chemical complexity of soluble polysaccharides and their interactions with other components of the diet make it difficult to define or isolate the single effects of SF components.

Dried beet pulp, a carbohydrate rich byproduct of the sugar industry, has been used as a partial source of energy in the rations of dairy cattle, growing calves; (El-Badawi and El-Kady, 2006) and rabbit's diets (Cobos et al., 1995; Volek et al., 2002; Zaza, 2005).

Regarding to the chemical analyses of sugar beet pulp, Abedo (2006) concluded that protein content of SBP ranged from 6.6 to $13.3 \%$ with an average of $9.9 \%$ compared with the requirements of most ruminants and mono gastric animals which are even high. Sugar beet pulp contains high crude fiber from 14.6 to $24.8 \%$ with an average $19.7 \%$, the fibrous carbohydrates of SBP are easily digested because of the amorphous structure of its cellulose and low content of its lignin.

However, SBP is deficient in fat, phosphorus, carotene and certain B- vitamins which have been reported as a reason for even lower availability of the nutrients in SBP (Morrison, 1959).

Practically, Garcia et al. (1993) reported that inclusion of $15 \%$ SBP in finishing rabbit diets decreased dietary energy and CP digestibility by $6 \%(\mathrm{P}<0.001)$, but non-significant effects were found on growth performance, empty body composition, DE and digestible CP efficiency for growth. High levels of SBP (35 and 50\%) led to leaner animals and did not affect $\mathrm{DE}$ intake but greatly impaired $(\mathrm{P}<.001) \mathrm{DE}$ and nitrogen efficiency, intake, growth rate, and dressing percentage in relation to the control diet. Inclusion of SBP increased the weight of gut contents $(\mathrm{P}<.001)$ and decreased cecal $\mathrm{pH}$ $(\mathrm{P}<.001)$, with no significant effect on mortality. Hussein et al. (2016) suggests utilizing new byproduct of processed sugar and it can be included in poultry diets to enhance growth performance in areas where an abundance of this sugar mill by-product is available.

The aim of this work was to evaluate the influence of partial and total replacement
Egyptian clover hay by sugar beet pulp in growing rabbit diets on growth performance, carcass traits, metabolic responses and the economical efficiency.

\section{MATERIALS AND METHODS}

This work was carried out at a private farm, Sharkia Governorate and the chemical analyses were undertaken at the laboratories of Poultry Department, Faculty of Agriculture, Zagazig University, Egypt.

Eighty unsexed weanling NZW growing rabbits of 5 weeks of age with an average initial weight $(610 \mathrm{~g})$ were randomly allotted to 5 equal groups. Each group contained 16 rabbits, with 8 replicates, each of two rabbits.

Five experimental diets were formulated for NZW rabbits from 5-13 weeks of age to cover all essential nutrient requirements for growing rabbits according to NRC (1977) as follows. The control diet (without SBP) contained 36\% clover hay $(\mathrm{CH})$, whereas the next four diets contained four levels of SBP (9, 18, 27 and 36\%) which represent replacement rates of 25, 50, 75 and $100 \%$ of $\mathrm{CH}$ in the control diet. Each experimental group of rabbits was allotted on one of the experimental diets.

All diets had nearly iso-nutritive value but were different in their components according to the purpose of study. Dried pelleted SBP was purchased from Dakahlia Sugar Company, Belkas manufacture, Dakahlia, Egypt. The composition and chemical analyses of all experimental diets are shown in Table 1.

All rabbits were kept under similar managerial and environmental conditions and were offered experimental diets ad lib. in pellet form, while clean fresh water was automatically available all the time by stainles steel nipples. Animals were housed in windowed rabbitry, with a three-level pyramid design cages made of galvanized wire net. Each cage measured of $50 \mathrm{~cm} \mathrm{~L} \times 25 \mathrm{~cm} \mathrm{~W} \times 40 \mathrm{~cm} \mathrm{H}$ and equipped with an automatic drinker nipple and a manual feeder. Before starting the experiment, all cages were cleaned and disinfected by fire. A photoperiod of 14-16 hrs., of day light was provided throughout the experiment. 
Table 1. Composition and chemical analyses of the experimental diets

\begin{tabular}{|c|c|c|c|c|c|}
\hline \multirow[t]{2}{*}{ Item } & \multirow{2}{*}{$\begin{array}{c}\text { Control } \\
\mathbf{0} \\
\end{array}$} & \multicolumn{4}{|c|}{ SBP substitution (\%) for $\mathrm{CH}$} \\
\hline & & 25 & 50 & 75 & 100 \\
\hline \multicolumn{6}{|l|}{ Component (\%) } \\
\hline Sugar beet pulp & - & 9.00 & 18.00 & 27.00 & 36.00 \\
\hline Clover hay & 36.00 & 27.00 & 18.00 & 9.00 & - \\
\hline Yellow corn grain & 36.00 & 28.00 & 19.00 & 13.00 & 8.50 \\
\hline Soybean meal (44\%) & 15.20 & 14.90 & 14.40 & 14.50 & 15.00 \\
\hline Wheat bran & 6.70 & 15.00 & 23.50 & 29.40 & 33.40 \\
\hline Soybean oil & - & - & 1.00 & 1.00 & 1.00 \\
\hline Molases & 5.00 & 5.00 & 5.00 & 5.00 & 5.00 \\
\hline DL-Methionine & 0.30 & 0.30 & 0.30 & 0.30 & 0.30 \\
\hline Vit. \& Min. Premix ${ }^{(1)}$ & 0.30 & 0.30 & 0.30 & 0.30 & 0.30 \\
\hline Salt (Nacl) & 0.50 & 0.50 & 0.50 & 0.50 & 0.50 \\
\hline Total & 100.00 & 100.00 & 100.00 & 100.00 & 100.00 \\
\hline \multicolumn{6}{|l|}{ Chemical analyses } \\
\hline \multicolumn{6}{|l|}{ a) Calculated analyses ${ }^{(2)}$} \\
\hline DE, Kcal / Kg & 2891 & 2852 & 2871 & 2860 & 2871 \\
\hline Calcium (\%) & 0.51 & 0.47 & 0.42 & 0.38 & 0.34 \\
\hline Phosphor (\%) & 0.36 & 0.43 & 0.51 & 0.56 & 0.59 \\
\hline Methionine + cystine & 0.65 & 0.65 & 0.65 & 0.66 & 0.66 \\
\hline Lysine (\%) & 0.75 & 0.78 & 0.80 & 0.83 & 0.87 \\
\hline \multicolumn{6}{|c|}{ b) Determined analyses (\%) } \\
\hline $\mathrm{DM}$ & 94.41 & 94.06 & 94.19 & 94.36 & 94.28 \\
\hline $\mathrm{OM}$ & 90.15 & 89.47 & 90.25 & 90.45 & 89.60 \\
\hline $\mathrm{CP}$ & 16.11 & 15.87 & 16.11 & 16.21 & 15.97 \\
\hline $\mathrm{CF}$ & 14.01 & 14.02 & 13.99 & 13.78 & 13.12 \\
\hline $\mathrm{EE}$ & 1.64 & 1.65 & 1.84 & 1.78 & 2.01 \\
\hline NFE & 62.65 & 62.52 & 62.25 & 62.59 & 63.18 \\
\hline Ash & 5.59 & 5.94 & 5.81 & 5.64 & 5.72 \\
\hline \multicolumn{6}{|l|}{ Cell wall constituents (\%) } \\
\hline NDF & 29.11 & 29.95 & 29.95 & 30.16 & 30.13 \\
\hline $\mathrm{ADF}$ & 18.51 & 20.41 & 20.15 & 19.93 & 19.65 \\
\hline ADL & 4.72 & 4.92 & 4.61 & 4.59 & 4.83 \\
\hline Hemicellulose & 10.60 & 9.54 & 9.80 & 10.73 & 10.48 \\
\hline Cellulose & 13.79 & 15.49 & 15.54 & 15.34 & 14.82 \\
\hline Cost/Kg diet PT, ${ }^{(3)}$ & 1.67 & 1.61 & 1.53 & 1.48 & 1.44 \\
\hline
\end{tabular}

(1) Grower Vit. and Min. Premix: Each Kg contains: vit. A 2.000.000 IU, vit. D3 150.000 IU, vit. E 8.33 g, vit. K 0.33 g, vit. B1 0.33 g, vit. B2 1.0 g, vit. B6 0.33 g, vit. B12 1.7 mg, pantothenic acid 3.33 g, Biotin $33 \mathrm{mg}$, Folic acid 0.83 g, Choline chloride 200 g, Zn 11.7 g, Mn 5 g, Fe 12.5 g, Cu 0.5 g, I 33.3 mg, Se 16.6 mg, and Mg 66.7 g.

(2) Calculated according to NRC (1977).

(3) Calculated according to the price of feed ingredients when the experiment was started. Based upon each unit weight (Kg) of SBP, CH, soybean meal, YCG, wheat bran, molases, DL-methionine, Vit. and Min. premix and salt (Nacl) equals to 1250.0, 1300.0, 3000.0, 2000.0, 1500.0, 600.0, 35000.0, 10000.0 and 250.0 PT, respectively. 
Using a high standard hygiene and careful management, the incidence of dangerous diseases was largely avoided and rabbits have never been treated with any kind of systematic vaccination or medication. The experimental period lasted for 13 weeks.

Individual live body weight, feed intake, daily weight gain, feed conversion ratio and viability rate were biweekly recorded during the experimental period.

Economical efficiency (EE) was calculated as the ratio between income (price of weight gain) and cost of feed consumption during the experimental period (Abd-Ella et al., 1988). The price of each $\mathrm{Kg}$ of the experimental diet was calculated according to the price of ingredients in the local market at the time of the experiment.

$$
\mathrm{EE}(\%)=\frac{\text { gain price }- \text { total cost }}{\text { total cost }} \times 100
$$

Where:

Gain price $=$ weight gain $\times$ price of $\mathrm{Kg}$ meat $(15.5 \mathrm{LE})$ and total cost $=$ feed intake $\times$ cost of Kg feed.

At the end of the experimental period (at 13 weeks of age), 4 rabbits were randomly chosen from each treatment. Assigned rabbits were fasted for 12 hours before slaughtering and were individually weighed as pre-slaughtering weight. Animals were slaughtered by cutting the jugular veins of the neck by sharp knife, upon the completion of bleeding, measured along the body, after skinning, the carcass was opened down and organs of digestive tract, stomach, small intestine and large intestine were removed, contents $\mathrm{pH}$ value measured and recorded by the $\mathrm{pH}$ meter, lengths and weights (full and empty) were measured, weights were proportioned to the live pre-slaughtering weight.

Also, at the end of the experimental period, one metabolism trail was conducted to estimate the digestibility coefficients of the five groups. Three rabbits from each group were individually housed in metabolic cages. Digestibility trail lasted 15 days ( 10 days as a preliminary period and 5 days as a collection period. Coprophagy was not prevented. Samples from both feed offered and dried faeces of each animal were daily taken during the collection period for chemical analyses (crude protein, crude fiber, ether extract and ash) which were carried out according to AOAC (1990). The total digestible nutrients (TDN) (\%) and digestible crude protein (DCP) was calculated according to Cheeke et al. (1982). The digestible energy (DE) was calculated according to Schneider and Flatt (1975) by using the following equation: $\mathrm{DE}$ $(\mathrm{kcal} / \mathrm{kg})=\mathrm{TDN} \times 44.3$. Cell wall constituents which were analyzed according to Goering and Van Soest (1970).

Data were subjected to analysis of variance, using the General Linear Model (GLM) procedure of SAS program (SAS, 2002). The model was assessed for different traits according to Snedecor and Cochran (1982). Differences among means within the same factor were tested by using Duncan's New Multiple Range Test (Duncan, 1955).

The statistical model used was:

$$
X_{i j}=\mu+B_{i}+E_{i j}
$$

Where:

$\mathrm{X}_{\mathrm{ij}}=$ an observation, $\mu=$ the overall mean, $\mathrm{B}_{\mathrm{i}}$ $=$ effect of dietary treatment $(\mathrm{I}=1,2, \ldots$ and 5$)$ and $\mathrm{E}_{\mathrm{ij}}=$ random error.

\section{RESULTS AND DISCUSSION}

\section{Growth Performance}

\section{Live body weight and body weight gain}

Results in Table 2 show the live body weight (LBW) as affected by the experimental diets. All rabbits have commenced with a nearly similar initial LBW which ranged between 607.50 and 608.13 g. This crated a suitable condition to appraise the effect of dietary treatments on the performance of experimental growing rabbits.

Results cleared that LBW at 11 and 13 weeks of age was significantly $(P<0.01)$ increased in rabbits fed diets containing SBP. It is clear that the increase in LBW conceded with increasing substitution level of $\mathrm{CH}$ with SBP up to $100 \%$. 
Table 2. Growth performance of NZW rabbits $(\overline{\mathrm{X}} \pm \mathrm{SE})$ as affected by SBP substitution of CH during the experimental periods (from 5-13 weeks of age)

\begin{tabular}{lcccccc}
\hline Item & \multicolumn{5}{c}{ SBP substitution (\%) for CH: } \\
\cline { 2 - 7 } & $\mathbf{0 \%}$ & $\mathbf{2 5 \%}$ & $\mathbf{5 0 \%}$ & $\mathbf{7 5 \%}$ & $\mathbf{1 0 0 \%}$ & Significance \\
\hline Live body weight (g) at & & & & & \\
5 weeks (Initial) & $607.50 \pm 0.94$ & $607.81 \pm 0.74$ & $607.82 \pm 0.52$ & $608.14 \pm 0.91$ & $608.13 \pm 0.83$ & NS \\
7 weeks & $931.50 \pm 2.02^{\mathrm{d}}$ & $937.31 \pm 1.18^{\mathrm{c}}$ & $943.75 \pm 1.59^{\mathrm{b}}$ & $959.19 \pm 0.74^{\mathrm{a}}$ & $927.38 \pm 1.27^{\mathrm{e}^{\mathrm{e}}}$ & $* *$ \\
9 weeks & $1417.75 \pm 2.30^{\mathrm{d}}$ & $1429.63 \pm 0.96^{\mathrm{b}}$ & $1433.56 \pm 2.22^{\mathrm{b}}$ & $1448.75 \pm 6.67^{\mathrm{a}}$ & $1408.81 \pm 1.31^{\mathrm{c}}$ & $* *$ \\
11 weeks & $2069.00 \pm 2.02^{\mathrm{c}}$ & $2095.88 \pm 6.91^{\mathrm{bc}}$ & $2103.56 \pm 8.58^{\mathrm{ab}}$ & $2125.63 \pm 13.91^{\mathrm{ab}}$ & $2136.69 \pm 17.19^{\mathrm{a}}$ & $* *$ \\
13 weeks (final) & $2469.00 \pm 5.35^{\mathrm{d}}$ & $2545.63 \pm 6.79^{\mathrm{c}}$ & $2603.13 \pm 2.74^{\mathrm{b}}$ & $2664.19 \pm 16.10^{\mathrm{a}}$ & $2517.06 \pm 17.73^{\mathrm{c}}$ & $* *$ \\
Daily weight gain (g) & & & & & & \\
$5-7$ weeks & $23.03 \pm 0.20^{\mathrm{d}}$ & $23.53 \pm 0.08^{\mathrm{c}}$ & $23.99 \pm 0.09^{\mathrm{b}}$ & $25.08 \pm 0.04^{\mathrm{a}}$ & $22.69 \pm 0.10^{\mathrm{e}}$ & $* *$ \\
7 -9 weeks & $34.73 \pm 0.23$ & $35.17 \pm 0.07$ & $34.99 \pm 0.19$ & $34.97 \pm 0.45$ & $34.39 \pm 0.13$ & NS \\
9-11 weeks & $45.62 \pm 0.91^{\mathrm{b}}$ & $47.59 \pm 0.45^{\mathrm{b}}$ & $47.86 \pm 0.67^{\mathrm{b}}$ & $48.35 \pm 0.92^{\mathrm{b}}$ & $51.99 \pm 1.26^{\mathrm{a}}$ & $* *$ \\
$11-13$ weeks & $29.76 \pm 1.38^{\mathrm{bc}}$ & $32.13 \pm 0.05^{\mathrm{bc}}$ & $35.68 \pm 0.67^{\mathrm{a}}$ & $38.47 \pm 1.10^{\mathrm{a}}$ & $28.44 \pm 1.35^{\mathrm{c}}$ & $* *$ \\
$5-13$ weeks & $33.29 \pm 0.13^{\mathrm{d}}$ & $34.60 \pm 0.12^{\mathrm{c}}$ & $35.63 \pm 0.04^{\mathrm{b}}$ & $36.72 \pm 0.28^{\mathrm{a}}$ & $34.38 \pm 0.49^{\mathrm{c}}$ & $* *$ \\
Viability rate (\%) & $93.75 \pm 6.25$ & $100.00 \pm 0.00$ & $100.00 \pm 0.00$ & $100.00 \pm 0.00$ & $93.75 \pm 6.25$ & NS \\
\hline
\end{tabular}

Means in the same row within each classification bearing different letters are significantly $(\mathrm{P}<0.05)$ different.

$* \mathrm{P}<0.05, * * \mathrm{P}<0.01$

At 7 and 9 weeks of age, replacing $\mathrm{CH}$ in the control diet with SBP up to $75 \%$ significantly increased $(\mathrm{P}<0.01)$ LBW (Table 2) while the complete replacement (100\%) of $\mathrm{CH}$ with SBP significantly $(\mathrm{P}<0.01)$ decreased LBW at only 7 weeks of age.

The beneficial effect of SBP may be related to the improvement in the nutrients digestion coefficients (Table 4). Belenguer et al. (2004) found that diets which contain SBP were better digested than that contains alfalfa hay.

The present results agree with Tag El-Din (1996) who reported that inclusion of SBP instead of $\mathrm{CH}$ in rabbit's diet gradually improved live weight with increasing the level of inclusion up to $30 \%$.

Results in Table 2 show that body weight gain (BWG) during 9-11 and 5-13 weeks of age were significantly $(\mathrm{P}<0.01)$ and gradually increased with increasing substitution of $\mathrm{CH}$ with SBP up to $100 \%$. However, at 5-7 weeks of age $100 \%$ substitution $\mathrm{CH}$ with SBP, significantly $(\mathrm{P}<0.01)$ decreased BWG. BWG was not significantly affected during 7-9 weeks of age due to substitution of $\mathrm{CH}$ with SBP. This indicated age related tolerance to SBP which increased with increasing age of rabbit may be due to fermentation of gut in terms of gut capacity, microbial and digestive enzymes.

In agreement with the present results, Tag ElDin (1996) found that the control group (0\% SBP) had the least value of daily BWG and the best one was obtained for the group fed 30\% SBP $(0 \% \mathrm{CH})$ during 8-13 weeks.

Viability rate (Table 2) varied between 93.75 and $100 \%$ for rabbits fed diets with different replacements of $\mathrm{CH}$ in control diet by SBP during the whole experimental period (5-13 weeks of age).

Results in Table 2 show that rabbits fed control diet (0\% $\mathrm{SBP})$ and $100 \%$ SBP replacement of $\mathrm{CH}$ recorded the lowest value of viability while rabbits fed 25, 50 and $75 \%$ SBP instead of $\mathrm{CH}$ recorded the highest one of viability.

\section{Feed intake and feed conversion}

Data revealed that daily feed intake (FI) was insignificantly decreased with increasing the most levels of CH substitution with SBP (Table 3). 
Table 3. Daily feed intake and feed conversion of NZW rabbits $(\bar{X} \pm$ SE) as affected by SBP substitution of CH during the experimental periods (from 5-13 weeks of age)

\begin{tabular}{|c|c|c|c|c|c|c|}
\hline \multirow[t]{2}{*}{ Item } & \multicolumn{6}{|c|}{ SBP substitution (\%) for $\mathrm{CH}$} \\
\hline & $0 \%$ & $25 \%$ & $50 \%$ & $75 \%$ & $100 \%$ & Significance \\
\hline \multicolumn{7}{|c|}{ Daily feed intake (g) } \\
\hline 5-7 weeks & $93.96 \pm 0.09$ & $93.44 \pm 0.14$ & $92.43 \pm 0.25$ & $92.34 \pm 0.80$ & $91.37 \pm 2.09$ & NS \\
\hline 7 -9 weeks & $119.02 \pm 1.14$ & $119.22 \pm 0.25$ & $117.81 \pm 0.78$ & $117.01 \pm 0.86$ & $117.86 \pm 0.84$ & NS \\
\hline 9-11 weeks & $135.63 \pm 3.22$ & $133.68 \pm 0.26$ & $133.10 \pm 0.53$ & $130.18 \pm 0.42$ & $134.73 \pm 2.29$ & NS \\
\hline 11-13 weeks & $124.51 \pm 2.17$ & $127.43 \pm 0.93$ & $126.85 \pm 0.47$ & $126.61 \pm 0.42$ & $123.66 \pm 0.60$ & NS \\
\hline 5-13 weeks & $118.28 \pm 1.32$ & $118.44 \pm 0.28$ & $117.55 \pm 0.37$ & $116.54 \pm 0.32$ & $116.91 \pm 0.77$ & NS \\
\hline \multicolumn{7}{|c|}{ Feed conversion (g feed / g gain) } \\
\hline 5-7 weeks & $4.08 \pm 0.04^{\mathrm{a}}$ & $3.97 \pm 0.01^{\mathrm{ab}}$ & $3.85 \pm 0.02^{b}$ & $3.68 \pm 0.03^{c}$ & $4.03 \pm 0.10^{\mathrm{a}}$ & $* *$ \\
\hline 7 -9 weeks & $3.43 \pm 0.05$ & $3.39 \pm 0.01$ & $3.37 \pm 0.04$ & $3.35 \pm 0.04$ & $3.43 \pm 0.02$ & NS \\
\hline 9-11 weeks & $2.98 \pm 0.07^{\mathrm{a}}$ & $2.81 \pm 0.03^{b}$ & $2.79 \pm 0.04^{\mathrm{b}}$ & $2.70 \pm 0.05^{\mathrm{bc}}$ & $2.60 \pm 0.08^{\mathrm{c}}$ & $* *$ \\
\hline 11-13 weeks & $4.31 \pm 0.16^{\mathrm{a}}$ & $3.97 \pm 0.03^{b}$ & $3.57 \pm 0.07^{\mathrm{C}}$ & $3.31 \pm 0.10^{c}$ & $4.40 \pm 0.15^{\mathrm{a}}$ & $* *$ \\
\hline 5-13 weeks & $3.70 \pm 0.04^{\mathrm{a}}$ & $3.53 \pm 0.01^{\mathrm{b}}$ & $3.39 \pm 0.01^{\mathrm{c}}$ & $3.26 \pm 0.02^{\mathrm{d}}$ & $3.61 \pm 0.06^{\mathrm{ab}}$ & $* *$ \\
\hline
\end{tabular}

Means in the same row within each classification bearing different letters are significantly $(\mathrm{P}<0.05)$ different. NS $=$ Not-Significant and ** $\mathrm{P}<0.01$

Table 4. Digestibility coefficients of NZW rabbits $(\bar{X} \pm S E)$ as affected by SBP substitution of $C H$ at 13 weeks of age

\begin{tabular}{|c|c|c|c|c|c|c|c|c|c|}
\hline \multirow[t]{2}{*}{ Item } & \multicolumn{6}{|c|}{ Digestion coefficients } & \multicolumn{3}{|c|}{ Nutritive values (As fed) } \\
\hline & DM & $\mathbf{O M}$ & $\mathbf{C P}$ & EE & CF & NFE & DCP & TDN & DE \\
\hline \multicolumn{10}{|c|}{ SBP substitution (\%) for $\mathrm{CH}$} \\
\hline $0 \%$ & $60.63 \pm 0.16^{\mathrm{c}}$ & $63.83 \pm 0.42$ & $74.50 \pm 0.09^{c}$ & $78.33 \pm 0.17^{\mathrm{a}}$ & $34.46 \pm 0.45^{\mathrm{a}}$ & $65.27 \pm 0.05^{\mathrm{d}}$ & $12.79 \pm 0.17^{\mathrm{d}}$ & $50.25 \pm 0.12^{c}$ & $2,226.08 \pm 5.17^{\mathrm{c}}$ \\
\hline $25 \%$ & $61.28 \pm 0.02^{\mathrm{abc}}$ & $63.72 \pm 0.77$ & $75.16 \pm 0.12^{b}$ & $78.55 \pm 0.06^{\mathrm{a}}$ & $32.90 \pm 0.10^{b}$ & $66.13 \pm 0.10^{\mathrm{c}}$ & $13.28 \pm 0.18^{\mathrm{C}}$ & $51.79 \pm 0.07^{b}$ & $2,294.30 \pm 3.15^{b}$ \\
\hline $50 \%$ & $60.96 \pm 0.38^{\mathrm{bc}}$ & $63.02 \pm 0.52$ & $75.50 \pm 0.18^{b}$ & $77.65 \pm 0.27^{\mathrm{ab}}$ & $33.33 \pm 0.72^{\mathrm{ab}}$ & $66.80 \pm 0.22^{b}$ & $13.66 \pm 0.07^{b}$ & $52.81 \pm 0.21^{\mathrm{a}}$ & $2,339.59 \pm 9.10^{\mathrm{a}}$ \\
\hline $75 \%$ & $61.71 \pm 0.27^{\mathrm{ab}}$ & $64.38 \pm 0.45$ & $76.05 \pm 0.16^{\mathrm{a}}$ & $77.15 \pm 0.68^{a b}$ & $32.41 \pm 0.24^{b}$ & $67.57 \pm 0.14^{\mathrm{a}}$ & $14.20 \pm 0.10^{\mathrm{a}}$ & $53.40 \pm 0.32^{\mathrm{a}}$ & $2,365.51 \pm 14.26^{\mathrm{a}}$ \\
\hline $100 \%$ & $61.86 \pm 0.27^{\mathrm{a}}$ & $64.88 \pm 0.33$ & $74.38 \pm 0.23^{c}$ & $76.77 \pm 0.70^{b}$ & $32.30 \pm 0.38^{b}$ & $64.92 \pm 0.11^{\mathrm{d}}$ & $13.15 \pm 0.04^{\text {cd }}$ & $50.99 \pm 0.46^{\mathrm{bc}}$ & $2,258.75 \pm 20.29^{\mathrm{bc}}$ \\
\hline Significance & $*$ & NS & $* *$ & $* *$ & $*$ & $* *$ & $* *$ & $* *$ & $* *$ \\
\hline
\end{tabular}


Even, there was a step wise decrease in DE with increasing inclusion level of SBP which would have a promptly effect on feed intake.

The reduction in FI for rabbits fed SBP may be due to high absorbing capacity and swelling capacity causing reducing rate of passage (Cheeke, 1987). Also, a reduced FI of chickens fed on diets with high inclusion levels of beet pulp, which could be accounted increased satiety due to reduced gastric emptying caused by distension of the duodenum (Sellers, 1977). It is worthy noting that SBP is known to have high water-holding capacity (Michel et al., 1988), which was probably responsible for the decreasing ileal digesta DM content of chickens fed on the higher inclusion levels of beet pulp. Similar to the present study, Tag El-Din (1996) reported that SBP in rabbit diet up to $30 \%$ had no effect on FI values over all the experimental period (8-13) weeks).

Sugar beet pulp substituted for $\mathrm{CH}$ with different levels (25, 50 and 75\%) in control diet significantly $(\mathrm{P}<0.05)$ improved feed conversion (FC) values of growing rabbits during 5-7, 9-11, 11-13 and 5-13 weeks of age (Table 3), while FC was insignificantly affected during 7-9 weeks of age.

Our results agree with Tag El-Din (1996) who found that the best value of FC was that of the group fed 30\% SBP in the diet, the overall means of FC of the control group ( $0 \%$ SBP: $30 \% \mathrm{CH})$ and that fed $7.5 \%$ SBP were approximately equal and both were significantly less than the other experimental groups. The best value of FC was that of the group fed 30\% SBP in the diet.

\section{Digestibility Coefficients and Nutritive Value of the Experimental Diets}

\section{Digestibility coefficients}

The obtained results of the digestibility trails (Table 4) in the experiment showed that the inclusion of SBP replacement of $\mathrm{CH}$ up to $75 \%$ had a significantly $(\mathrm{P}<0.05)$ positive effect on the digestibility coefficients of CP and NFE. While, inclusion of $100 \%$ SBP substitution of $\mathrm{CH}$ in control diet had a significantly $(\mathrm{P}<0.01)$ effect on the digestibility coefficients of $\mathrm{CP}$ and NFE recorded the highest values in rabbits fed
75\% SBP substitution of $\mathrm{CH}$ as compared to the control diet. On the other hand, digestibility coefficients of CF was decreased gradually ( $\mathrm{P}<$ 0.05 ) with increasing SBP level up to $100 \%$ substitution for $\mathrm{CH}$. Inclusion of SBP did not significantly affect on digestion of OM. Digestibility coefficient of EE was significantly $(\mathrm{P}<0.01)$ decreased when the diet included $100 \%$ SBP instead of $\mathrm{CH}$.

\section{Nutritive value}

The nutritive values of DCP, TDN and DE were significantly $(\mathrm{P}<0.01)$ affected by SBP instead of $\mathrm{CH}$ in rabbit diet (Table 4).

It is worthy noting that each of DCP, TDN and $\mathrm{DE}$ were gradually increased $(\mathrm{P}<0.01)$ when 25, 50 and $75 \%$ SBP replaced $\mathrm{CH}$ in control diet. It is clear that, increasing the substitution of SBP up to $100 \%$ by $\mathrm{CH}$ insignificantly increased DCP, TDN and DE contents in the diet. In contrary, Tag El-Din (1996) found that there were no significant differences in each of DE, TDN and DCP among feeding treatments due to inclusion SBP instead $\mathrm{CH}$.

\section{Carcass characteristics}

All carcass traits studied were not significantly affected by feeding the SBP diets (Table 5). The results were in agreement with Tag El-Din (1996) who found that no significant effect with respect of all carcass traits which were slightly improved with increasing SBP level in the diet from 0 up to $30 \%$. Also, Volek et al. (2004) found that dressing percentage was similar in diets containing 35\% SBP to the control diet.

\section{Gastrointestinal Tract Segments, Organs Weight and pH Values}

\section{Digestive tract length}

The results obtained on gastrointestinal tract segments at 13 weeks of age are presented in Table 6. It could be noticed that the substitution of SBP for $\mathrm{CH}$ in control diet did not significantly affect the length of each part of the gastrointestinal tract studied (stomach, small intestine and large intestine). However, Arslan and Saatci (2003) showed that the goslings diet replacement by alfalfa, grass and SBP with 5, 10 and $15 \%$, small intestine and caecum lengths of 
Table 5. Some carcass traits studied of NZW rabbits $(\bar{X} \pm S E)$ as affected by SBP substitution of $\mathrm{CH}$ at 13 weeks of age

\begin{tabular}{lccccccccc}
\hline Item & $\begin{array}{c}\text { Slaughter } \\
\text { Wt. (g.) }\end{array}$ & $\begin{array}{c}\text { Blood } \\
\mathbf{( \% )}\end{array}$ & $\begin{array}{c}\text { Offal } \\
\mathbf{( \% )}\end{array}$ & $\begin{array}{c}\text { Liver } \\
\mathbf{( \% )}\end{array}$ & $\begin{array}{c}\text { Kidneys and } \\
\text { Spleen (\%) }\end{array}$ & $\begin{array}{c}\text { Heart } \\
\mathbf{( \% )}\end{array}$ & $\begin{array}{c}\text { Total } \\
\text { giblets (\%) }\end{array}$ & $\begin{array}{c}\text { Dressing } \\
\mathbf{( \% )}\end{array}$ & $\begin{array}{c}\text { Carcass } \\
\mathbf{( \% )}\end{array}$ \\
\hline SBP substitution (\%) for CH & & & & & & & & & \\
$\mathbf{0 \%}$ & $2,461.25$ & $3.33 \pm 0.10$ & $21.20 \pm 0.16$ & $5.46 \pm 0.15$ & $2.03 \pm 0.06$ & $0.74 \pm 0.03$ & $8.23 \pm 0.19$ & $56.40 \pm 0.35$ & $52.12 \pm 0.22$ \\
$\mathbf{2 5 \%}$ & $2,523.75$ & $3.32 \pm 0.09$ & $21.60 \pm 0.40$ & $5.45 \pm 0.08$ & $2.05 \pm 0.05$ & $0.75 \pm 0.02$ & $8.25 \pm 0.11$ & $56.04 \pm 0.34$ & $51.77 \pm 0.35$ \\
$\mathbf{5 0 \%}$ & $2,593.75$ & $3.61 \pm 0.04$ & $21.11 \pm 0.19$ & $5.64 \pm 0.12$ & $2.07 \pm 0.02$ & $0.76 \pm 0.02$ & $8.47 \pm 0.12$ & $56.14 \pm 0.24$ & $51.75 \pm 0.10$ \\
$\mathbf{7 5 \%}$ & $2,626.75$ & $3.40 \pm 0.05$ & $21.08 \pm 0.34$ & $5.72 \pm 0.16$ & $2.11 \pm 0.06$ & $0.75 \pm 0.02$ & $8.58 \pm 0.16$ & $56.24 \pm 0.37$ & $51.79 \pm 0.23$ \\
$\mathbf{1 0 0 \%}$ & $2,503.75$ & $3.49 \pm 0.07$ & $21.21 \pm 0.33$ & $5.52 \pm 0.13$ & $2.04 \pm 0.03$ & $0.75 \pm 0.02$ & $8.31 \pm 0.13$ & $56.23 \pm 0.10$ & $51.92 \pm 0.35$ \\
Significance & & NS & NS & NS & NS & NS & NS & NS & NS \\
\hline
\end{tabular}

NS= Not-Significant.

Table 6. Digestive system length of NZW rabbits $(\bar{X} \pm S E)$ as affected by SBP substitution of $C H$ at 13 weeks of age

\begin{tabular}{|c|c|c|c|c|c|c|}
\hline \multirow[t]{2}{*}{$\overline{\text { Item }}$} & \multirow[t]{2}{*}{ Body weight (g.) } & \multicolumn{5}{|c|}{ Length (cm.) } \\
\hline & & Body & Digestive tract & Stomach & Small intestine & Large intestine \\
\hline \multicolumn{7}{|c|}{ SBP substitution (\%) for $\mathrm{CH}$} \\
\hline $\mathbf{0 \%}$ & $2,461.25$ & $50.83 \pm 1.39$ & $544.51 \pm 0.86$ & $29.96 \pm 0.22$ & $333.90 \pm 0.49$ & $180.65 \pm 0.69$ \\
\hline $25 \%$ & $2,493.75$ & $50.75 \pm 1.22$ & $545.45 \pm 0.39$ & $30.80 \pm 0.66$ & $333.83 \pm 0.62$ & $180.83 \pm 0.53$ \\
\hline $50 \%$ & $2,526.25$ & $50.98 \pm 1.26$ & $545.20 \pm 1.24$ & $29.64 \pm 0.27$ & $334.95 \pm 0.62$ & $180.61 \pm 1.23$ \\
\hline $75 \%$ & $2,485.00$ & $50.83 \pm 1.42$ & $545.48 \pm 0.63$ & $31.34 \pm 0.30$ & $334.18 \pm 0.58$ & $179.96 \pm 0.58$ \\
\hline $100 \%$ & $2,458.75$ & $50.65 \pm 0.94$ & $544.71 \pm 1.04$ & $30.20 \pm 0.40$ & $334.70 \pm 0.65$ & $179.81 \pm 1.21$ \\
\hline Significance & & NS & NS & NS & NS & NS \\
\hline
\end{tabular}

NS= Not-Significant. 
groups were also statistically different. On the other hand, Arslan (2005) found that the length of examined gastrointestinal tract sections (small intestine and ceacum) were not affected by feeding regimes (containing 10\% SBP) in geese at 6 and 12 weeks of age.

\section{Digestive tract activity (pH values)}

The effect of substitution of SBP for $\mathrm{CH}$ in rabbit diets on the $\mathrm{pH}$ of digestive tract (stomach, small intestine, caecum and colon) were showed in Table 7.

The $\mathrm{pH}$ of the content gastrointestinal organs was not affected by SBP substitution for $(25,50$, 75 and 100\%) CH. On the other hand, Falcaoe et al. (2004) found that the $\mathrm{pH}$ of caecum contents was significantly affected by the source of fiber being lower in beet pulp diets. El-Abed et al. (2011) found that the type of diet didn't affect on growth rate and stomach $\mathrm{pH}$. While the inclusion of SBP or their fractions decreased the caecum pH. Arslan and Saatci (2003) showed that the goslings diet replacement by alfalfa, grass and SBP with 5, 10 and 15\%, a part from jejunum $\mathrm{pH}, \mathrm{pH}$ of glandular stomach, duodenum, ileum and caecum statistically differ between the groups. However, Arslan (2005) found that the $\mathrm{pH}$ value of examined gastrointestinal tract sections (small intestine and caecum) content was not affected by feeding regimes (Containing 10\% SBP) in geese at 6 and 12 weeks of age.

\section{Gastrointestinal organs weight and their content}

The effect of substitution of SBP for $\mathrm{CH}$ on gastrointestinal weight and their content are shown in Table 8. From obtained results it is clear that, SBP had no significant effect on empty digestive tract weight or their content. ElAbed et al. (2011) reported that SBP diet with their soluble or insoluble fractions, the insoluble fraction seems to be the main responsible of the high total digestive tract weight. They added that the soluble and insoluble fractions of SBP produce different effects on the gastrointestinal tract. Also, Falcaoe et al. (2004) reported that beet pulp diets gave heavier stomachs and caecums. Volek et al. (2004) found that the weights of digestive organs (stomach, small intestine, caecum and colon) of rabbit fed diets potato pulp, SBP and wheat bran were significantly different in caecum, but, other organs were not significantly affect. In addition, Arslan and Saatci (2003) showed that the weight of glandular stomach, gizzard, small intestine and caecum were significantly different between different groups of goslings diet replaced by alfalfa, grass and SBP with 5, 10 and 15\%. However, Arslan (2005) found that, the weight of gastrointestinal tract sections (small intestine and ceacum) was not affected by feeding regimes (containing 10\% SBP) in geese at 6 and 12 weeks.

\section{Economical evaluation}

According to guide of economical evaluation, average FI per rabbit, price per Kg. diet, total feed cost per rabbit, average BWG, price per kg. Body weight, selling price, net return, economical efficiency and relative economical efficiency are presented in Table 9.

\section{Net return (NR)}

Feeding dietary treatments resulted in a positive effect of improving NR being 17.792 to 22.211 LE showing that SBP substitution of $\mathrm{CH}$ in growing rabbits up to $75 \%$ increased NR by $24.8 \%$ over the control group, being the highest NR compared to other experimental groups, while the total SBP substitution of $\mathrm{CH}$ decreased NR by $11.5 \%$ from that of the highest NR group (75\% substitution). This advantage may be due to their current lower price compared to the control.

The feed cost to produce one LE of meat ranged from 0.303 to $0.383 \mathrm{LE} / \mathrm{LE}$ showing that the highest feed cost to produce one LE of meat was recorded for rabbits received the control diet, while the least one was that of incorporation of $27 \%$ (75\% substitution level) SBP in the growing diets.

The net return from one LE feed cost was the least for rabbits received the control diet (2.611 $\mathrm{LE} / \mathrm{LE}$ ), while it was the highest (3.30 LE/LE) for rabbits received 27\% SBP in growing diets recording $26.4 \%$ more than that of the control diet. 
Table 7. Digestion tract content $\mathrm{pH}$ of NZW rabbits $(\overline{\mathrm{X}} \pm \mathrm{SE})$ as affected by SBP substitution of $\mathrm{CH}$ at 13 weeks of age

\begin{tabular}{lcccc}
\hline Item & \multicolumn{2}{c}{$\mathbf{p H}$ value of the content } \\
\cline { 2 - 5 } & Stomach & Small intestine & Large intestine & Caecum \\
\cline { 3 - 5 } & & & & \\
\hline SBP substitution (\%) for CH & & $7.18 \pm 0.03$ & $6.10 \pm 0.04$ & $6.53 \pm 0.03$ \\
$\mathbf{0 \%}$ & $1.68 \pm 0.03$ & $7.18 \pm 0.05$ & $6.10 \pm 0.09$ & $6.50 \pm 0.04$ \\
$\mathbf{5 \%}$ & $1.65 \pm 0.06$ & $7.20 \pm 0.04$ & $6.13 \pm 0.09$ & $6.50 \pm 0.07$ \\
$\mathbf{5 0 \%}$ & $1.65 \pm 0.06$ & $7.23 \pm 0.05$ & $6.08 \pm 0.05$ & $6.50 \pm 0.09$ \\
$\mathbf{7 5 \%}$ & $1.68 \pm 0.03$ & $7.28 \pm 0.11$ & $6.08 \pm 0.09$ & $6.53 \pm 0.06$ \\
$\mathbf{1 0 0 \%}$ & $1.65 \pm 0.06$ & NS & NS & NS \\
Significance & NS & &
\end{tabular}

NS= Not-Significant.

Table 8. Digestive tract organs weight of NZW rabbits $\left(\bar{X}_{ \pm}\right.$SE) as affected by SBP substitution of CH at 13 weeks of age

\begin{tabular}{|c|c|c|c|c|c|c|c|c|c|}
\hline \multirow[t]{2}{*}{ Item } & \multirow{2}{*}{$\begin{array}{c}\text { Slaughter Wt. } \\
\text { (g) }\end{array}$} & \multicolumn{2}{|c|}{ Digestive tract Wt. (\%) } & \multicolumn{2}{|c|}{ Stomach Wt. (\%) } & \multicolumn{2}{|c|}{ Small intestine Wt. (\%) } & \multicolumn{2}{|c|}{ Large intestine Wt. (\%) } \\
\hline & & Empty & Content & Empty & Content & Empty & Content & Empty & Content \\
\hline \multicolumn{10}{|c|}{ SBP substitution (\%) for $\mathrm{CH}$ : } \\
\hline $\mathbf{0 \%}$ & 2461.25 & $5.13 \pm 0.01$ & $13.94 \pm 0.09$ & $1.10 \pm 0.01$ & $2.46 \pm 0.03$ & $1.97 \pm 0.01$ & $0.87 \pm 0.02$ & $2.73 \pm 0.01$ & $14.05 \pm 0.10$ \\
\hline $25 \%$ & 2493.75 & $5.11 \pm 0.02$ & $13.94 \pm 0.04$ & $1.09 \pm 0.01$ & $2.47 \pm 0.02$ & $1.97 \pm 0.02$ & $0.87 \pm 0.02$ & $2.73 \pm 0.01$ & $14.12 \pm 0.07$ \\
\hline $50 \%$ & 2526.25 & $5.12 \pm 0.04$ & $14.02 \pm 0.08$ & $1.10 \pm 0.03$ & $2.45 \pm 0.03$ & $1.96 \pm 0.02$ & $0.89 \pm 0.02$ & $2.74 \pm 0.02$ & $14.20 \pm 0.09$ \\
\hline $75 \%$ & 2485.00 & $5.14 \pm 0.02$ & $14.14 \pm 0.17$ & $1.10 \pm 0.03$ & $2.45 \pm 0.08$ & $1.97 \pm 0.02$ & $0.88 \pm 0.04$ & $2.73 \pm 0.01$ & $14.33 \pm 0.09$ \\
\hline $100 \%$ & 2458.75 & $5.13 \pm 0.03$ & $13.93 \pm 0.07$ & $1.10 \pm 0.01$ & $2.46 \pm 0.03$ & $1.98 \pm 0.02$ & $0.87 \pm 0.02$ & $2.73 \pm 0.01$ & $14.09 \pm 0.04$ \\
\hline Significance & & NS & NS & NS & NS & NS & NS & NS & NS \\
\hline
\end{tabular}

NS= Not-Significant. 
Table 9. Economical evaluation of NZW rabbits as affected by SBP substitution of CH during the period from 5-13 weeks of age

\begin{tabular}{|c|c|c|c|c|c|c|}
\hline \multirow[t]{2}{*}{$\overline{\text { Item }}$} & \multirow[t]{2}{*}{ Unit } & \multirow{2}{*}{$\begin{array}{c}\text { Control } \\
(0 \%)\end{array}$} & \multicolumn{4}{|c|}{ SBP substitution (\%) for $\mathrm{CH}$} \\
\hline & & & $25 \%$ & $50 \%$ & $75 \%$ & $100 \%$ \\
\hline Average FI / rabbit (5-13 weeks) & $\mathrm{Kg}$ & 6,624 & 6,633 & 6,583 & 6,526 & 6,547 \\
\hline Price/kg diet & $\mathrm{LE}$ & 1.67 & 1.61 & 1.53 & 1.48 & 1.44 \\
\hline Total feed cost / rabbit & LE & 11,061 & 10,679 & 10,072 & 9,658 & 9,427 \\
\hline Average BWG (5-13 weeks) & $\mathrm{Kg}$ & 1,862 & 1,938 & 1,995 & 2,056 & 1,909 \\
\hline Selling price / meat & LE & 28,853 & 30,036 & 30,927 & 31,869 & 29,589 \\
\hline NR & $\mathrm{LE}$ & 17,792 & 19,357 & 20,856 & 22,211 & 20,161 \\
\hline Economical efficiency & & 1.61 & 1.81 & 2.07 & 2.30 & 2.14 \\
\hline Relative economical efficiency & $(\%)$ & 100 & 112.59 & 128.57 & 142.86 & 132.92 \\
\hline Feed cost to produce one LE of meat & LE/LE & 0.383 & 0.356 & 0.326 & 0.303 & 0.319 \\
\hline Relative change of feed cost/LE of meat & $(\%)$ & 100 & 93.0 & 85.1 & 79.1 & 83.3 \\
\hline NR from One L.E feed cost & $\mathrm{LE} / \mathrm{LE}$ & 2.611 & 2.813 & 3.071 & 3.300 & 3.140 \\
\hline Relative change of NR & $(\%)$ & 100 & 107.7 & 117.6 & 126.4 & 120.3 \\
\hline
\end{tabular}

Price / kg body weight: $15.5 \mathrm{LE}$ as the market at time of the experiment.

It is worthy noting that, $75 \%$ substitution of $\mathrm{CH}$ with SBP was more economically than that of $75 \%$ substitution of YCG. This increase obtained with SBP substitution of CH draws the attention towards SBP substitution of $\mathrm{CH}$ at $27 \%$ as a practical level of inclusion.

\section{Economical efficiency}

Feeding growing rabbits on control diet gave the lowest economical efficiency value (1.61), whereas the best efficiency value (2.30) was for the rabbits fed $75 \%$ SBP substitution of $\mathrm{CH}$, followed by 25, 50 and 100\% SBP replacement for $\mathrm{CH}$ being, 1.81, 2.07 and 2.14, respectively over the control.

These results are supported by those of feed conversion, in which rabbits fed on dietary SBP diets utilized feed more efficiently than the control diet ( $0 \%$ SBP). The relative economical efficiency was superior (142.86) of the group fed $75 \%$ SBP substitution of $\mathrm{CH}$, followed by those of 100, 50 and 25\% being, 132.92, 128.57 and 112.59, respectively over the control.

In general, it may be concluded that growing rabbits can tolerate SBP even at a level of $27 \%$
(75\% substitution of $\mathrm{CH}$ ) improving economical efficiency.

It is worthy noting that the highest economical efficiency $(2.30 \%)$ in case of this experiment is lower than that of $\mathrm{CH}$ experiment at the same substitution level of SBP showing that from practical and economical substitution of SBP for $\mathrm{CH}$ is more preferable than that for cereals.

\section{Recommendation}

From practical and economical point of view further investigations are advisable to test complete substitution of $\mathrm{CH}$ with biologically or chemically treated SBP in formulating does and grower rabbit diets under local conditions.

\section{REFERENCES}

Abd-Ella, M.M., G.A.E. El-Sayaad, M.K. Hathout and M.A. Khalil (1988). Effect of feeding ammoniated rice straw with ElMufeed on performance of lambs. Ann. Agric. Sci., Moshtohor, 36 (3): 1405 -1417.

Abedo, A.A. (2006). A study on the use of sugar 
beet pulp in the feed mixtures for ruminants. Ph.D. Thesis, Fac. Agric., Ain Shams Univ., Egypt.

AOAC (1990). Official Methods of Analysis $16^{\text {th }}$ Ed. Published by the AOAC. Washington, DC.

Arslan, C. (2005). Effects of feeding by diets supplemented with grass meal and sugar beet pulp meal on growth slaughter performance and some blood parameters in geese. Revue Med. Vet., 156 (10): 475-481.

Arslan, C. and M. Saatci (2003). Bulky feeds in the intensive fattening of goslings. 1. Effects of grass, alfalfa and sugar beet pulp on growth slaughter performance and some blood parameters in geese. Revue Med. Vet., 154 (10): 633-638.

Belenguer, A., J. Bal Cells, L. Abecial and M. Decoux (2004). Effect of carbohydrate type on milk production and caecal environments in lactating rabbits. World Rabbit Sci., 12:119-132.

Carabaño, R.I., S. Badiola, A.I. Chamorro, P. Garcia, M.S. Garcia-Ruiz, A. GarciaRebollar, I. Gomez-Conde, N. Gutierrez, M.J. Nicodemus, J.C. Villamide and E. de Blas (2008). New trends in rabbit feeding: Influence of nutrition on intestinal health. Span. J. Agric. Res., 6:15-25.

Cheeke, P.R. (1987). Rabbit Feeding and Nutrition. Acad. Press, Orlando, FL.

Cheeke, P.R., N.M. Patton and G.S. Tempelton (1982). Rabbit Production $5^{\text {th }}$ Ed Int. Print. And Publ. Danville II.

Cobos, A., L. Hoz, M.I. Cambero and J.A. Ordonez (1995). Sugar beet pulp as an alternative ingredient of barley in rabbit diets and its effect on rabbit meat. Meat Sci., 39:113-117.

Duncan, D.B. (1955). Multiple Range and Multiple F-Test. Biomet., 11:1-42.

El-Abed, N., R. Delgado, R.I. Abad, C. Romero, A. Fernandez and M.J. Villamide (2011). Effect of sugar beet pulp fibre fractions on growth performance, fecal digestibility and digestive physiology in rabbits around weaning. Giornate di Coniglicoltura ASIC,
75-77.

El-Badawi, A.Y. and R.I. El-Kady (2006). Effect of partial replacement of concentrates with sugar beet pulp on performance, carcass characteristics and energy utilization of growing sheep. J. Agri. Biol., $8: 3$.

Falcaoe, C.L.P.H., J.P.B. Freire and L. CastroSolla (2004). Effects of Alfalfa hay, wheat bran or beet pulp, with or without sunflower oil, on caecal fermentation and on digestibility in the rabbit. Anim. Feed Sci. and Technol., 117: 131- 149.

Garcia, G., J.F. Galvez and J.C. De Blas (1993). Effect of substitution of sugar beet pulp for barley in fishing rabbits diets for on growth performance and on energy and nitrogen efficiency. J. Anim. Sci., 71: 1823-1830.

Goering, H.K. and P.J. Van Soest (1970). Forage Fiber Analysis'. Agriculture Handbook No. 379, USDA-ARS. (US Government Printing Office: Washington, DC).

Hussein, A.S., J. Al Ghurair, P.G.K. John, H.M. Habib and M. Sulaiman (2016). Graded levels of sugar syrup in broiler rations and its effect on growth performance and blood biochemical parameters. Anim. Nut., (3): 1-6.

Kebede, T., T. Lemma, E. Tadesse and M. Guru (2008). Effect of level of substitution of sweet potato (Ipomoea batatas L.) vines for concentrate on body weight gain and carcass characteristics of browsing Arsi-Bale goats. J. Cell and Anim. Biol., 2 (2) : 036-042.

Michel, F., J.F. Thibault and J.L. Barry (1988). Preparation and characterisation of dietary fibre from sugar beet pulp. J. Sci. Food and Agric., 42: 77-85.

Mirzaei-Aghsaghali, A. and N. Maheri-Sis (2008). Nutritive value of some agroindustrial by-products for ruminants - A review. World J. Zool., 3 (2): 40-46.

Morrison, F.B. (1959). Feeds and Feeding. $22^{\text {nd }}$ Ed. The Morrison Pub. Comp., Clinton, Iowa, USA.

NRC (1977). National Research Council. Nutrient requirements of domestic animals. Nut. Requir. Rabbits. Nat. Acad. Sci. Washington, DC., USA. 
SAS (2002). SAS Institute Inc., Cary, NC, USA. NOTE: SAS Proprietary Software Version 9.00 (TS M0).

Schneider, B.H. and W.P. Flatt (1975). The Evaluation of Feed Through Digestibility Experiments. Georgia Univ., Press Athens, Georgia, USA, 423.

Sellers, A.F. (1977). Genesis and propagation of motor activity in the digestive tract. In Duke's Physiol. Domestic Anim. [M. J. Swenson, editor]. New York: Ithaca., 233239

Snedecor, G.W. and W.G. Cochran (1982). Statistical Methods. $7^{\text {th }}$ Ed. Iowa stat Univ., Press. Ames. Iowa, USA.

Tag El-Din, T.H. (1996). Productive performance of meat rabbits as affected by partial replacement of clover hay by okra and sugar beet processing by-products. J. Agric. Sci., Mansoura Univ., 21 (12): 4339 - 4350.

Volek, Z., V. Skrivanova, M. Marounek and L.
Zita (2004). Replacement of starch by pectin and chicory- inulin in the starter diets of early weaned rabbits. Effect on growth, health status, caecal traits and iscosity of the small intestinal content. Czech J. Anim. and Feed Sci., 1022- 1028.

Volek, Z., V.M. Skrivanova, S.M. Marounek and P. Klein (2002). Performance, digestive anatomy and caecal parameters in rabbits fed diets differing in digestible fiber content. $53^{\text {rd }}$ Ann. Meet. EAAP, Cairo.

Xiccato, G., A. Trocino, D. Majolini, M. Fragkiadakis and M. Tazzoli (2011). Effect of decreasing dietary protein level and replacing starch with soluble fibre on digestive physiology and performance of growing rabbits. Anim., 5 (8):1179-1187.

Zaza, G.H.M. (2005). Effect of incorporation of biologically treated sugar beet pulp. as a non - conventional feed-stuff in the diets of growing rabbits. The $4^{\text {th }}$ Int. Conf. on Rabbit Prod. in Hot Climate, Sharm El- Sheikh, Egypt, 267-274. 


\section{تأثير استبدال دريس البرسيم المصري بتفل بنجر السكر علي أداء الأرانب النامية

$$
\text { صلاح الاين سيد أبو العلا ـ فايز محمد رضا }
$$

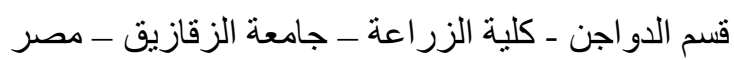

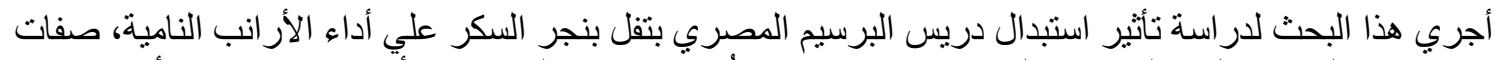

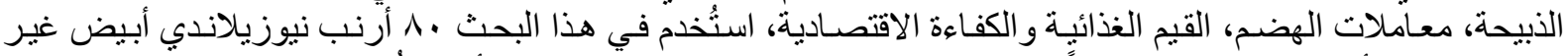

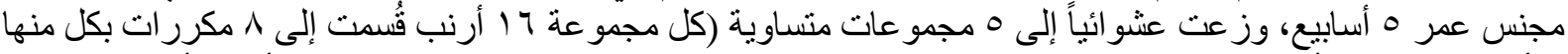

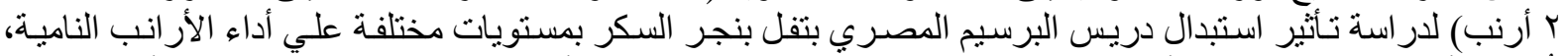

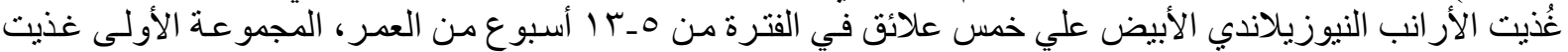

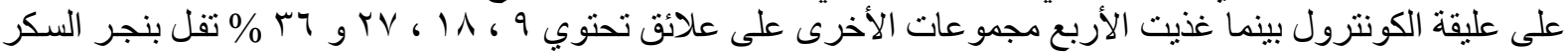

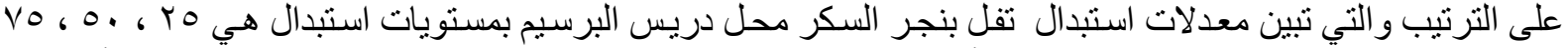

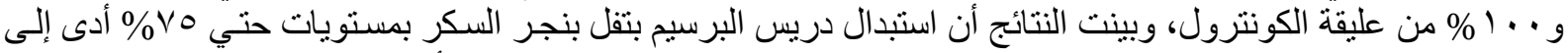

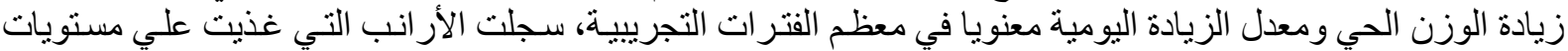

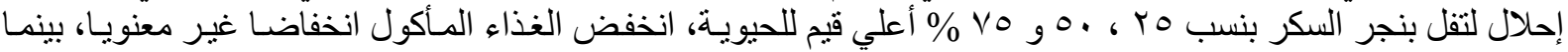

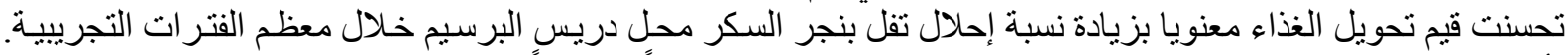

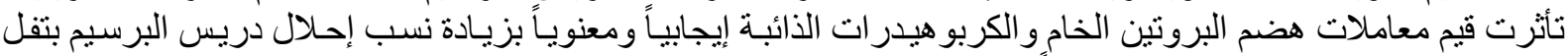

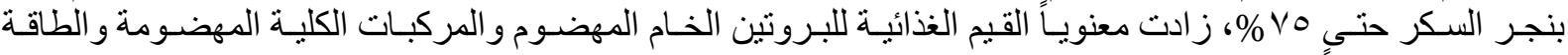

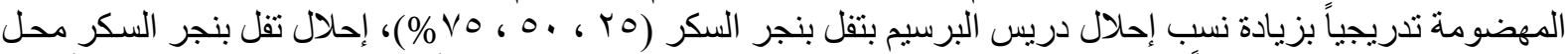

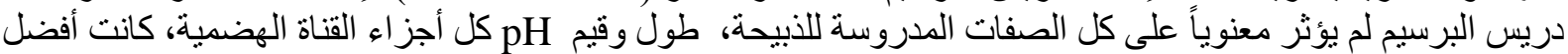

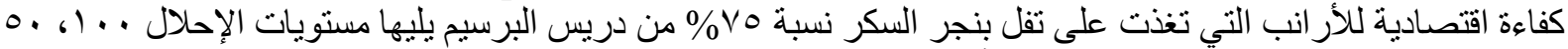

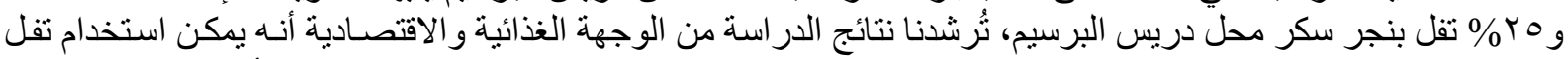

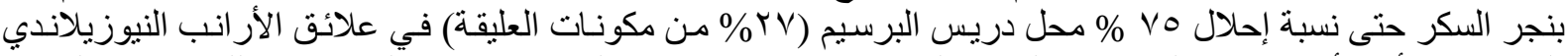

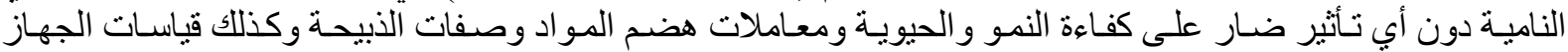

